This is the author's version. Final version published in Journal of Common Market

Studies: https://doi.org/10.1111/jcms.12811

\title{
The Transnational Constitution of Europe's Social Market Economies: A Question of Constitutional Imbalances?
}

\author{
Poul F. Kjaer \\ Copenhagen Business School
}

\begin{abstract}
Throughout its history the European integration process has not undermined but rather strengthened the autonomy of Member States vis-à-vis wider societal interests in relation to political economy, labour markets and social provisions. Both the 'golden age nation state' of the 1960s as well as the considerable transformations of Member State political economies over the past decades, and especially after the euro-crisis, was to a considerable degree orchestrated through transnational, most notably European, arrangements. In both cases the primary objective has been to strengthened state capacities of public power and law against the encroachment of private interests into the state. In spite of this continuity considerable changes can however be observed in the substantial economic policies advanced due to the switch from a Keynesian to a monetarist economic paradigm. It is suggested that the debate on constitutional imbalances between the EU's economic and social constitutions should be seen in this light.
\end{abstract}

Keywords: Corporatism, European Coal and Steel Community, neo-corporatism, economic and social constitution, transnationalism. 


\section{Introduction}

Is the European integration process running counter to Member State attempts of maintaining welfare protection and a social market economy? And is the EU's 'economic constitution' inherently imbalanced emphasising economic freedoms rather than social protection? The answer to these questions, central to this special issue, is bound up on the benchmark from where one departs. The most common place benchmark is the 'golden age nation state' of the 1960s which often is portrayed as the epitome of a successful institutional and legal stabilisation of national political economy regimes based on a social market economy approach to labour market regulation and welfare provisions (e.g. Hurrelmann et. al., 2007; Streeck, 2008). The 'golden age nation state' is typically portrayed as a result of national compromises between different social classes and political forces leading to an equilibrium between market logics and social logics which subsequently has been undermined by external forces, most notably in relation to increased globalisation and advancement of the European integration process (Scharpf, 1988; Scharpf, 2010).

Confirming the insight that it was not before the mid-twentieth century that institutionally stable nation states and nationwide political economy regimes emerged in Western Europe one might however ask how the golden age nation state itself came into existence? Providing an alternative to methodological nationalist outlooks (Chernilo, 2007) and the assumption of the purely national origin of the 'golden age nation state' the overall argument advanced in this article is that the golden age nation states themselves, including their regimes of political economy, to a large extent were children of transnational developments thereby indicating that the existence of extensive transnational legally entrenched frameworks is a condition rather than a problem for national autonomy. So even if the current structure of the EU's economic constitution is "imbalanced" this does not per se imply that transnational arrangements are inherently contradictory to the existence of 
extensive welfare provisions only that the substantial content of the EU's economic constitution and the wider legal norms derived from it might pose a challenge to national welfare regulation. ${ }^{1}$ The question of "constitutional imbalances" might, therefore, be rephrased by asking what type of political economy regime the EU is promoting and its compatibility with the diverse institutional arrangements of the Member States.

The overall argument is unfolded in four steps. The starting point is a critique of the dominant schools of political economy scholarship and their tendencies to promote methodological nationalist perspectives and the 'epistemological barrage' they construct by installing a certain image of the golden age nation state as their benchmark and point of departure. Instead the wider issue of social market economy and political economy is reconceptualised as an issue of the relation between public and private power.

Secondly, taking a brief look at pre-1952, i.e. pre-WWII, developments it is argued that the central change when comparing the respective organization of the pre- and postWWII political economy regimes in Western Europe was a switch from the relative primacy of private power and law to the relative primacy of public power and law. The reconfiguration of national political economy regimes including social provisions can, therefore, only be seen in conjunction with the more general constitutional transformations of nation states unfolding in the aftermath of WWII.

Thirdly, that the switch from the relative pre-dominance of private power to the relative pre-dominance of public power came about through a multi-faceted process which combined local, national and transnational dimensions. One of the central outcomes of this process, the emergence of singular nationwide institutional frameworks of political economy

1 See the contribution of Niamh Nic Shuibhne in this special issue for how this has developed in case law. 
and social protection enjoying a considerable degree of coherency, was very much orchestrated by transnationally organized coalitions which massively influenced both the general constitutional set-up of post-WWII Western European 'golden-age nation states', as well as their regimes of political economy. Western European nation states including their political economy regimes were not just 'rescued', as famously argued by Alan Milward (Milward, 2000), by transnational developments, such as the European integration process, but were instead re-constituted in a far more profound manner. This was particular but not only the case for the German social-market political economy model which since its formation has been considered distinct (Streeck, 1997; Tüselmann \& Heise, 2000, pp. 16276) or alternatively as the paradigmatic model for continental Europe (Hall \& Soskice, 2001). Fourthly: That the reworking of the EU's 'macro-economic constitution' in the wake of the euro-crises also has been aimed at expanding rather than diminishing state autonomy vis-à-vis societal forces and interests located outside the state. This potentially provide Member States with increased possibilities to develop universal welfare provisions while at the same time curtailing 'societal based', i.e. corporatist welfare arrangements. In other words: European integration does not per se undermine welfare protection but favours a particular form for the organisation of such protection, just as recent developments in relation to the handling of the euro-zone crisis might be seen as a continuation of previous attempts in European history to strengthen national institutions of public power vis-à-vis private power through transnational means. That said substantial changes can be observed due to the switch from demand-side to supply-side economics, i.e. from Keynesian to monetarist paradigm. This switch is however a general switch which is not particular for transnational policymaking as it is just as engrained in national settings. 


\section{Private and Public Power beyond Methodological Nationalism}

Two of the hereto dominant bodies of the literature on European political economy are the (neo-) corporatist literature mainly associated with Philippe C. Schmitter, working in close collaboration with Gerhard Lembruch, which dominated the scene in the 1970s and 1980s (Schmitter, 1974, p, 105; Schmitter \& Lembruch, 1979) and the Varieties of Capitalism approach associated with Peter Hall and David Soskice (Hall \& Soskice, 2001) which gained prominence in the first decade of the new millennium.

One of the central arguments advanced by Schmitter was that interwar corporatism was 'state-centred', while post-WWII neo-corporatism was 'society-centred' (Schmitter, 1974, p, 105; Schmitter \& Lembruch, 1979). The perspective advanced in this article is the exact opposite. The relative dominance of strong public law-framed institutional frameworks is regarded as a post-WWII phenomenon which was strongly facilitated by the European integration process and which substituted the localistic, paternalistic and privatistic frameworks which had remained dominant both before WWI and in the interwar period.

Second, the VoC approach, which gained centre stage in the first decade of the new millennium, has, as its starting-point, the assumption that the political economy is 'the preserve of the nation-state' (Hall \& Soskice, 2001, p. 4), and this is assumed to be the case for both co-ordinated and liberal market economies. If one observes, as the VoC approach does, national political economy regimes when already up and running, i.e. in a static manner, this might at a first glance be regarded as correct. But, if the focus is shifted to the process of the emergence of national political economy regimes, a different picture appears as 
the political economy institutions of post-WWII Western Europe emerged as part of a dual (trans-)national process. ${ }^{2}$

In contrast to these two dominant approaches and following Franz L. Neumann, the German theorist and practitioner of what has been termed 'social law' (including, but also going beyond, labour law), a special take on the character of public power as constituted through public law can be developed. In this context, public power is conceptualized as a generalized, abstract and non-paternalistic phenomenon which stands in contrast to the paternalistic, particularistic and localistic power of private interests. A form of public power which is different from private power due to the way it is legally constituted as public law frameworks is what provides public power with its essential characteristics of generalisability and abstractness (Kjaer, 2017; Neumann, 1933).

Also following Neumann one might argue that not only (West) German society, the context within which Neumann wrote, but the vast majority of other national contexts in Europe did not become social spaces enjoying a high level of coherency and unity constituted through institutionalised public power until after WWII. Until then, even under the National Socialist regime, German society was characterized by a conglomerate structure of partly overlapping and partly conflictual local and national - and, indeed, transnational institutional formations which were pre-dominantly privatistic rather than public (Neumann, 1944, p. 467ff; Bast, 1999). This was, albeit with considerable variation, also the case in other European settings and that to a degree which makes Weimar Germany a paradigm case rather than the sort of exception it was depicted as in the Sonderweg ('special path') literature (Hinde, 1998), i.e. institutionally weak states was the normality rather than the exception in the majority of interwar continental Europe (Thornhill, 2016). It is in this light that the central

2 See also the contribution of Mathieu Segers to this special issue. 
transformations of the German and the wider (Western) European political economy and its institutional social market economy arrangements after WWII should be seen.

\section{The Turn to Privatistic Corporatism in Interwar Europe}

As emphasized by Colin Crouch, Denmark and Switzerland were the only European countries in which a unified and nationwide political economy regime was in place by the end of the nineteenth century (Crouch, 1994, p. 80ff). In the rest of Europe, industrial relations and social affairs remained a largely company internal, profession based, local or regional affair. Real changes only started to set in during WWI (Maier, 1975, p. 11; Feldman, 1977), and, when they did occur, it was only with great regional and national differences in term of intensity and maturity. Centralization on a national scale went, for example, further in Germany than in France, which only attained a superficial degree of centralization during the war (Maier, 1975, p. 71ff).

It was in this context that 'corporatism' became widespread and popular both as a multi-faceted ideology and as an institutionalized social praxis in the interwar period (Manoilescu, 1929). Re-constructing the evolution of corporatism in his landmark essay of 1974, Schmitter introduced an important distinction between interwar corporatism and postWWII neo-corporatism (Schmitter, 1974). Following Mihail Manoïlsco’s distinction between 'pure corporatism' (corporatisme pur) and 'subordinated corporatism' (corporatisme subordonné), he characterized interwar corporatism as being primarily state-centred, since the societal organization of interest representation was supposedly transformed into vehicles of state power. Societal corporatism, characterized by industrial self-organization, on the other hand, was seen as a concomitant element of democratic post-WWII welfare societies (Schmitter, 1974, p. 102ff). But, rather than an encroachment of state-based public power into 
society, the interwar turn to corporatism implied a (re-) privatization of public power and an increased reliance on paternalistic modes of societal organization which had only been superficially suppressed by the newly constituted states (Kjaer 2015; Neumann 1930a; Neumann1930b; Neumann, 1930c).

This paternalist set-up was also mirrored in the welfare policy vis-à-vis employees, which throughout the interwar period, to a large extent, remained an internal dimension of firm organization, with large-scale conglomerates engaged in providing housing, consumer goods through company stores, health schemes, and so forth (Hilger, 1998). Throughout Europe, the emergence of state-based welfare provisions was a very gradual process which in its outset mainly was focused on formalising pre-existing 'societal' arrangements, typically firm or profession based and often with a local or regional, rather than a national, reach. Thus, prior to the post-WWII era, contract law, rather than state legislation, remained the most important tool for organising welfare and social provisions in Europe. This was also the case for industrial policy more generally at both the national and transnational level. A clear illustration of the latter is the establishment of the international steel cartel in 1926 (restructured as the International Steel Export Cartel in 1933). The cartel, situated in Luxembourg, served as a framework for transnational industrial coordination on the basis of contract law, i.e. international private law, rather than international public law (Barbezat, 1991).

\section{The Transnational Constitution of Nation States and National Political Economies}

As epitomized by the establishment of the European Coal and Steel Community (ECSC) in 1952, Europe's political economy institutions were fundamentally re-structured in the immediate post-WWII period. However, due to the experience with the International Steel 
Cartel as well extensive transnational cartels in relation to majority of other industrial goods ranging from coal, to rubber and aluminium (e.g. Bertilorenzi, 2013; Schröter, 2013), this restructuring did not emerge from out of nowhere. Rather, the ECSC was based upon an institutional legacy providing the essential backdrop for its formation. In addition, the ECSC emerged both within and was part of a far more fundamental re-configuration of (trans-) national society unfolding from the end of the war until the mid-1950s. A dual (trans-) national constitutional moment profoundly reshaping society on a European-wide and partly global scale unfolded (Brunkhorst, 2014, p. 436ff; Fossum \& Menéndez, 2011, p. 78ff). Strongly backed by the resources and powers of the United States, an intense level of transnational 'founding acts' occurred from the Bretton Woods Agreements in 1944, through the establishment of the United Nations in 1945, and the GATT and the OEEC in 1947 (and, with the latter, the Marshall Plan running from 1948 to 1952), and the Council of Europe in $1949 .^{3}$

The allied occupation of Germany from 1945 to 1955 was also a transnational endeavour which included a vast amount of countries and led to the emergence of complex institutional frameworks aimed at sorting out differences and co-ordinating policies. Two central examples of this were the Allied Steel Trusteeship, taking control of the West German steel industry immediately after the war, and the International Authority for the Ruhr, which was active from 1949 to 1952 . The latter was also established and controlled by the Western Allied powers, and was introduced as part of the process leading to the establishment of the German Federal Republic in 1949, in order to maintain allied control over core elements of the German economy, in particular the coal and steel industries, after the formation of the Federal Republic. The Ruhr Authority came to act as the preceding organization to the ECSC

3 See also the contribution of Mathieu Segers to this special issue. 
and was dissolved, handing over its activities, with the initiation of the ECSC, thereby highlighting the simultaneousness and interwoven relations between the national reconstitution of (West) Germany and the re-constitution of the transnational framework for coal and steel.

The re-constitution of the West German coal and steel industry came to serve as a template for a far more profound re-structuring of western European political economies as the establishment of the Federal Republic was far from being the only national re-constitution process taking place. Almost all Western European states granted themselves new constitutions or substantially revised their existing constitutions between 1945 and 1957. A central element of these processes was intense cross-border exchanges leading to a high level of 'constitutional borrowing'. One consequence of this was that five of the six states which eventually came to act as the founding states of the European Communities in 1957, inscribed a commitment to international and European co-operation and integration in their constitutions in the same period. Belgium was the only exception here. Thus one may speak of a multi-faceted dual (trans-) national constitutional process through which European nation states and numerous transnational frameworks were simultaneously re-constituted (Brunkhorst, 2014, p. 436ff; Fossum \& Menéndez, 2011, p 78ff).

The ECSC was, at least among its central architects, always considered to be a mere forerunner of a much more ambitious project of European integration. But apart from this, the ECSC, as well as its predecessors in the allied occupation framework, also gave a central impetus to the fundamental reform of national, in particular, but by no means exclusively, German, political economy institutions. In terms of ownership structure, the US dominated occupation of Western Germany marked the beginning of a process of disentanglement and of re-structuring of the ownership structures in West Germany industry. As part of this overall effort, all assets of the major steel companies were, for example, seized in 1946/47 
and, after a lengthy bargaining process with owners, management and employees, eventually broken up into 23 new companies, thereby providing a considerable decentralization of the industry, thus implying both a substantial reduction in the vertical integration of the industry and its horizontal links with other industries (Herrigel, 2000). In the years following the foundation of the Federal Republic, this development was, to some extent, rolled back, but nonetheless left an industry which had been substantially transformed through a transnational process involving a complex coalition ranging from the American, British and French governments, German and international companies, trade unions organized at local, regional and national levels in the German context, as well as, particularly after the founding of the Federal Republic, German political representatives (Warner, 1989; Warner, 1996). As such, the biggest change in the structural composition of ownership in the history of the modern German steel industry was brought about through a multi-faceted (trans-) national process.

As for the related issue of market construction, the ECSC became the central framework for the steel industry, instigating a regime in which free market principles and interventionism were combined and that in a manner which served as a template for the wider reconstruction of national political economies (Gillingham, 1991, p. 190). The ECSC was very much inspired by the framework for allied co-operation during the two world wars, with its secretariat modelled on the allied shipping secretariat, and was, just like the secretariat of interwar International Steel Cartel, based in Luxembourg. Cartels were banned within the ECSC framework, just as mergers and acquisitions were subject to approval (Kaiser \& Schot, 2014, p. 204ff). Thus, factually, the ECSC became a competition (antitrust) regulator, and, in this capacity, it became the frontrunner for the simultaneous establishment of the German national competition law and a general European competition regime laid down in the Treaty 
of Rome in $1957 .^{4}$ But, at the same time, direct market intervention by the High Authority of the ECSC was specifically foreseen in Articles 59 and 61 of the ECSC Treaty, and, although cartels were internally prohibited in Article 65, this was not the case in relation to exports, thereby providing the basis for a new export cartel made up of Belgian-, French-, Germanand Luxembourg-based steel producers to be founded in 1953 (Kaiser \& Schot, 2014, p. 206ff). Market construction, in other words, underwent a phase of increased Europeanization, which, in many ways, was a continuation of the interwar transnational practices. The core transformation taking place was therefore not so much a shift from national to transnational arrangements as a re-framing of transnational arrangements within a generalized and institutionally more stable treaty-based international public law framework, rather than the contract-based international private law framework which had been the dominant characteristic of earlier arrangements as epitomised in the International Steel Cartel. As such, the launch of the ECSC indicated an increase in the relative centrality of public power vis-àvis private power, in so far as public modes of organization and regulation took centre stage for the first time.

As for employer/employee relations in the German context, a central division had existed between the American and British governments, as the latter, following the simultaneous efforts of the Labour government of Clement Attlee to nationalize numerous British industries, had advocated for widespread nationalization of German industry, whereas the American government wished to maintain private ownership. The compromise solution,

4 For a historical overview, see the contributions in Patel and Schweitzer, (2013). For a detailed view on the relation between EU competition law and the concept of a social market economy see the contribution of Anna Gerbrandy in this issue and for the historical dimension also the contribution of Laurent Warlouzet. 
first introduced in the steel industry, ended up being a reform of the German framework for co-determination (Mitbstimmung), guaranteeing employees' representative's places on company boards, and employer/employee relations in general. The consequence was that the International Authority for the Ruhr became instrumental for the co-determination reform (Gillingham, 1991, p. 190 \& 199ff; Herrigel, 2000). Co-determination had a long history in Germany, but a new overall framework for both the Western and the Eastern occupation zones was established by the four-power Allied Control Council in April 1946, ${ }^{5}$ which subsequently was substantiated at regional level. In West Germany, these regional variations were ironed out in relation to coal and steel through the establishment of a unitary framework in $1951{ }^{6}$, and this reform eventually came to serve as the template for co-determination in the entire West German industry as adopted in $1952{ }^{7}$ thereby once again highlighting the status of the steel industry as an strategic 'avant-garde industry'. Although formally adopted by the Federal Republic, the essential components of these reforms were, however, already developed in the negotiations between the Western allied powers, and the employers and employees within the framework of the International Authority for the Ruhr prior to the

5 See Kontrollratsgesetz Nr. 22, available at: http://www.verfassungen.de/de/de45-49/krgesetz22.htm. As an Allied Control Council decision it applied to both the Eastern and the Western Occupation Zones.

6 Gesetz über die Mitbestimmung der Arbeitnehmer in den Aufsichtsräten und Vorständen der Unternehmen des Bergbaus und der Eisen und Stahl erzeugenden Industrie, available at https://www.gesetze-im-internet.de/bundesrecht/montanmitbestg/gesamt.pdf.

7 Betriebsverfassungsgesetz 1952 vom 11. Oktober 1952, available at:

http://www.boeckler.de/pdf/mbfoe_betriebsverfassungsgesetz_1952.pdf; Hugo Sinzheimer et al. (1976, p. 168). 
foundation of the Federal Republic, just as the Ruhr Authority remained in control at the time of the passing of the reforms. The was also the case with the reform of the framework for collective-bargaining autonomy (Tarifautonomie) which was developed in a similar manner and which was finalized in April 1949, one month before the establishment of the Federal Republic (Kronstein, 1952, p. 204ff). The core institutional pillars of employer/employee relations in post-WWII West Germany was, therefore, not developed within a nation state framework, but instead emerged through a multi-faceted process with local, regional, national and transnational dimensions.

This development was further re-enforced through the development of centralized business associations and trade unions, which was also advanced by the occupying powers. Employers established in 1947 a loose framework for co-operation throughout the Western occupation zones (Arbeitsgemeinschaft der Arbeitgeber der Westzone), followed by a more institutionally fortified central secretariat in 1948 (Zentralsekretariat der Arbeitgeber des Vereinigten Wirtschaftsgebietes) leading to the establishment in January 1949, three months before the founding of the Federal Republic, of the Confederation of German Employers' Associations (Bundesvereinigung der Deutschen Arbeitgeberverbände). In a similar fashion, regionally organized trade unions emerged right after the end of the war. Subsequently, they were merged through the establishment of the Confederation of German Trade Unions (Deutscher Gewerkschaftsbund) in October 1949, one month after the foundation of the Industriegewerkschaft Metall, providing a unified West German trade union for steel and other metal workers. These unions were unitary unions (Einheitsgewerkschaften) aimed at the across-the-board inclusion of all employees, and, as such, markedly different than the kind of politically specified socialist, liberal and Christian trade unions of the Weimar period (Richtungsgewerkschaften). Thus, simultaneously with the foundation of the Federal Republic, the first establishment of a singular and centralized framework for employer and 
employee representation throughout the entire state territory emerged in the West German context. Factually, this new neo-corporatist system thereby became bound to the West German state, serving as an extended institutional formation of the state. As such, this neocorporatist framework was, in direct contrast to the perspective advanced by Schmitter, very much a state-centred framework which, in contrast to the implicit perspective intrinsic to the VoC literature, furthermore, came about through a transnationally instigated process. Or, more precisely expressed, the neo-corporatist framework became an institutional repository of public power, in so far as it, in the parlance of Neumann, became generalized, formalized and proceduralized. Generelised in the sense that the new neo-corporatist institutions was aimed at securing an across the board inclusion capturing the German economy in its entirety and formalised and proceduralized through its anchoring within public law and a legally entrenched organisational setup providing a stable framework for bargaining, cooperation and conflict resolution between employers and employees and for their relations with the state. As such the post-WWII framework obtained a fundamentally different structure than the informal, privatistic and localistic corporatism of the interwar period (Kjaer, 2014).

This move towards a new public power-based neo-corporatist framework was also reflected in the general welfare policy, in so far as the following years was characterized by substantial welfare reforms strongly reducing the paternalistic character of social policy. The Basic Law of the Federal Republic, as agreed upon by the Western allied powers and German political representatives constituted a 'democratic and social state', where welfare provisions, as paradigmatically expressed in the American, British and French inspired 1957

8 Article 20, 1 of The Basic Law of the Federal Republic of Germany from 23 May 1949. Available at: http://www.cvce.eu/content/publication/1999/1/1/7fa618bb-604e-4980-b66776bf0cd0dd9b/publishable_en.pdf. 
reform of the West German retirement system, were generalized upon the basis of an individualized insurance principle, which broke with the paternalistic ideas of poverty relief (Fürsorge) which had been dominant until then (Torp, 2016, p. 243ff). ${ }^{9}$

Thus, the central components of the neo-corporatist 'social-market economy' institutional framework guiding the West German political economy in the post-WWII era were, in fact, only partially developed at national level, and mainly before the Federal Republic came into existence. A more precise description of the emergence of the post-WWII political economy regime of Germany, and thereby the concept of a 'social market economy', seems to be that it was constituted through a dual (trans-) national process, rather than being 'the preserve of the nation-state' as argued within VoC (Hall \& Soskice, 2001, p. 4). This constitution of the German ‘social market economy’ was furthermore intrinsically linked to and part of a more fundamental state-building exercise as embodied in the objectives of the American occupation policy. ${ }^{10}$

Although less pronounced outside West Germany, this was also the case in many other Europeancontexts. In France, only timid moves towards a generalized welfare and labour market system emerged in the late nineteenth century. These moves were re-enforced but not in a fundamental manner during WWI and in the interwar period. First, on the eve of WWII, moves were made towards unifying the existing plethora of social security and labour

${ }^{9}$ The speed and intensity of this development however varied within different types of welfare arrangements. Most notably the German health insurance system maintained a more diverse character with different schemes for different types of employees.

10 A policy which Neumann greatly influenced through his concept of the four 'Ds' consisting of de-nazification, democratisation, demilitarisation and de-cartelization (Neumann, 1944). 
market regimes within a single public law-based framework. These efforts were, at the level of planning, continued not only by the Vichy regime, but also by the competing Free France exile government in London. The plans of the Free French were heavily influenced by the Social Insurance and Allied Services Report, the so-called Beveridge Report, of 1942, which provided the cornerstone for the reformation of the British welfare and labour market system in the early post-war period, and, as such, provided the basic framework for the British political economy until the late 1970s. In France, already in the autumn of 1945, these plans were turned into practical policy through the merger of the various mainly private law-based social security systems into a single public law-based generalized framework, covering, among other things, pensions, occupational injury, health and housing. ${ }^{12}$ Furthermore, the French constitution of the Fourth Republic of 1946 introduced a right to social security and also re-inforced the right to form occupational associations, business associations and trade unions, and the right to strike. However, a central dimension of these development was that they unfolded within the transnational context provided by the Marshall Plan and other international initiatives, which came with detailed 'Troika-style' strings attached (DeLong \& Eichengreen, 1993), as well as more subtle American attempts to counter the possibility of Communist takeovers (Esposito, 1994),

11 Thereby highlighting the impact of WWII on the formation of post-war national political economies. The Beveridge Report is available at: http://news.bbc.co.uk/2/shared/bsp/hi/pdfs/19_07_05_beveridge.pdf.

12 Entitled 'Un plan complet de sécurité sociale, visant à assurer à tous les citoyens des moyens d'existence, dans tous les cas où ils sont incapables de se le procurer par le travail, avec gestion appartenant aux représentants des intéressés et de l’État’. See Carsalade, (2002, p. 347ff). 
To this, came the 'London experience' of the exiled governments of the countries which had been occupied by the Axis powers during the war. With the exception of the Danish government, all of them were based in London, and here they spent the majority of the time planning for the post-war period. Plans which were developed within a setting much resembling present day Brussels, in so far as intense exchanges and learning processes unfolded between the European government élites. The present-day 'Brussels-scene' might, in this perspective, be seen as an institutionalization of the WWII London experience, and the consequence was that a central impetus for the reform wave that was to unfold throughout Western Europe, and not just in France, in the golden age era of Les Trente Glorieuses (the glorious thirty years) and the Wirtschaftswunder (economic miracle) which followed WWII, was not developed 'at home', but in an extremely trans-nationalized setting, instead (Harste, 2015, p. 210).

\section{Constitutional Imbalances in the European Economic Constitution?}

The move towards the establishment of the ECSC was part of a far larger (trans-) national reconstitution of European society, a move which had, at its common core, the introduction of a primacy of public law vis-à-vis private law-based arrangements. This was a fundamental novelty since it was first then that a form of modern public power emerged which was factually capable of breaking institutionalised private power throughout most Western European countries.

The ECSC, although based upon a principle of free competition, also maintained strong interventionist measures. Moreover, exports to third countries were not covered by the free market principle, thereby allowing cartel practices to continue for a considerable part of the post-WWII period. As such, the relation between the interwar International Steel Cartel 
and the ECSC needs to be seen in a gradualized manner. One the one hand, the ECSC was, in many respects, an institutional continuation of the cartel, but, at the same time, the establishment of the ECSC implied a gradual evolution towards emphasizing increased competition. As already indicated, the key difference was that the private law-based interwar framework was substituted with a highly formalized public law framework. As such, the launch of the ECSC did not mark the beginning of the European integration process, but rather the beginning of the end of this process.

The consecutive rounds of enlargement of what is now called the European Union (EU) from 1974 onwards, most notably the enlargements with Greece, Portugal and Spain in the 1980s, and with the Central and Eastern European countries in the new millennium, furthermore implied that these states, as part of their accession process, had to re-structure their political economies fundamentally. In particular, the re-structuring of the former Communist states became an affair which had many of the facets of the process leading to the establishment of the West German state and its political economy regime, in so far as it was a process which combined national and transnational dimensions (Bugaric, 2014).

After the financial crisis, which became visible in 2007, and the subsequent crisis within the Euro-zone, a number of southern European countries were effectively put 'under administration' by the so-called Troika consisting of the European Central Bank, the European Commission and the IMF. The Troika is pursuing fundamentally different substantial economic policy objectives than those advanced by the early post-WWII transnational regimes, as it reflects the general switch from demand-side to supply-side approaches within the economic discipline from the 1970s onwards. As such, it might be said to reflect the general switch from a largely Keynesian and social democratic or social liberal policy regime, to a largely neoclassic or neo-liberal policy regime (Kjaer, 2015, p. 159f; 
Kjaer \& Olsen, 2016). ${ }^{13}$ At the core of the intervention however lie a problem which is similar to what was promoted vis-à-vis other European countries in the immediate postWWII period, namely the attempt to install a well-defined realm of generalised public power capable of fencing off private interests, endogamous policy networks and vested interests in contexts, notably in Greece, where the factual autonomy and capacity of the state to structure social exchanges across the board had always been weak. Much like Weimar Germany, Greece has throughout the $20^{\text {th }}$ century been characterised by "cultural dualism", i.e. a dualism between formal state institutions and local and paternalistic networks, which factually short-circuited the functioning of the Greek state (Dimandourous, 2013). Informal networks which was combined with strongly formalised vested interest which factually operated as "states within the state" making the Greek state a conglomerate of interestsbearing bodies rather than a unified body of abstract and generalised and therefore singular public power constituted through public law in the sense of Neumann. The breaking of such vested interest was, together with "budgetary balancing", at the core of the Troika intervention.

The case of Greece was however only a particular intense variant of the general overhaul of the EU's 'macro-economic constitution, as pursued since the outbreak of the

13 In allusion to Structural Marxism, this neo-classic or neo-liberal paradigm might also be characterized as an expression of 'Structural Liberalism', in so far as it has a deterministic supposedly scientific basis while seeing economic structures as the core determinant of societal evolution. See Kjaer, (2015, p.159f). In a broader sense the neo-liberal turn might also be seen as implying a re-privatization of public power which might have similar consequences as the breakdown of the integrity and functionality of public power in the interwar period. For a detailed unfolding of this argument, see Kjaer and Olsen, (2016). 
Euro-crisis. Through nine major initiatives ranging from the "Europe 2020 Strategy" launched in March 2010 to the still ongoing development of a "Banking Union”, the macroconstitutional constitutional framework of the EU Member States in general and the Eurozone Member States in particular has been carried out. ${ }^{14} \mathrm{~A}$ central element of this transformation is however the attempt to design policies and institutional formations aimed at strengthening state autonomy. Balanced budget requirements for example tend to strengthen the hand of national finance ministries in the attempt to fence off national budgets from societal demands for spending, the same goes for the "Six Pack Directives" requirement concerning the establishment of independent institutions of macroeconomic and budgetary forecasting. Member States, such as Spain, which struggles with strong centrifugal developments, i.e. a difficulty for the political centre to control its periphery, the new tools furthermore reinforces the clout of the centre, by giving it tools to control budgetary spending on the local and regional level. Thus the overhaul of the (euro-zone) economic constitution seems to potentially reinforce rather than diminishing the power of Member States vis-à-vis wider societal forces and interests.

Considerable similarities are therefore evident between the earlier reconstruction of in particular West-Germany but also the wider Western Europe in the immediate post-WWII period and the "Troika-experience”, as they share the overall aim of installing a not only formally but also factually autonomous and across the board form of legally constituted public power. As such both of them might be considered examples of transnational statebuilding exercises. At the same time, as previously indicated, the economic paradigm used as the tool box for this aspiration has profoundly changed through the switch from the

14 For an overview see Joerges 2016.

15 For a more detailed account of this see Kjaer, 2017 
Keynesian to the Monetarist paradigm. In addition, the substantial policy recommendations are aimed at developing generalised across the board solutions to issues such as labour market contracts, pension schemes. This goes against the logic and institutional traditions characterising many of the corporatist economies of Southern Europe which, in particular in relation to labour market institutions, are characterised by high levels of fragmentation, thereby massively increasing the level of intrusion and upheaval created in those countries by transnationally developed policies.

The 'three worlds of welfare capitalism', the scene setting approach to European political economy of the 1990s, factually de-emphasised the most southern part Europe mainly focusing on the British, Austrian/Dutch/German and Nordic experiences which were conceived of as respectively representing liberal, corporatist and universal forms for organising welfare and social market economies (Esping-Andersen, 1990). ${ }^{16}$ This deemphasising of the southern model is also apparent in the Troika's attempt to achieve a fundamental reconstruction of the institutional setup up of most notably Greek but also Cypriot, Irish, Spanish, Portuguese and more indirectly also French and Italian political economy institutions from 2010 onwards. The still ongoing attempt seem to be guided by a recipe blending various north-west European experiences and transposing those to Southern Europe, i.e. a German focus on balanced budgets, with a British/Nordic focus on flexible labour markets and singularly organised systems for welfare services such as health care and retirement.

The question of 'constitutional imbalances' might therefore need to be rephrased into a question of the normative foundation serving for the transnational imposing of a relatively specific social-market economy model on first West-Germany and subsequently and

16 See also the introduction to this special issue. 
gradually via European institutions on the rest of Europe. The transnational constitution of European states implies a (not so) gentle modernisation of those states, i.e. the deliberate break-down of existing structures of social cohesion and embeddedness, typically of a localistic and paternalistic nature, and the attempted replacement of these with new generalised and abstract frameworks for the stabilisation of economy and welfare.

The tendency to opt for institutional solutions similar to those which have emerged in North-western European contexts and the disfavouring of the institutional models predominant in the most southern Members States, furthermore works in tandem with the particular institutional features of the EU acting as the central transnational institutional site in the current European context. The EU is a constitutional conglomerate consisting of several partly overlapping, partly mutually reinforcing and partly contradictory functionally delineated constitutional orders, i.e. an economic, a juridical, a political, a social and a security constitutional order. Each of these constitutions are characterised by a hierarchy of norms, with constitutional norms serving as a 'higher law' structuring substantial norms at a lower level (Tuori, 2010). The different constitutional orders of the EU have however evolved in an evolutionary fashion and they are therefore characterised by different degrees of “completeness” and enjoying a different status and reach. The 'social constitution', most notably, remain partial and embryonic with a number of social rights stated at the level of higher law, i.e. in the treaty, while little substance has been provided to them at the lower level. This again means that the EU in its reforming efforts is factually limited in its potential choices of which welfare models to promote as the in-balance between economic and social competences is likely to tilt the institutional interest of EU institutions towards emphasising the economic dimension.

\section{Conclusion}


When viewed in the light of the immediate post-WWII experience, and irrespective of the profound change in the substantial policies advanced, the current transnational reconfiguration of a number of European states and their political economy regimes is not, a new thing. Not only the German political economy regime and the German model of a social market economy, but, in fact, the majority of continental European states and their political economy regimes seem to have emerged through processes which, to a high degree, or maybe even mainly, were transnational in character. Or, to put it differently, both the golden-age nation states of the post-war period in Western Europe and the Southern and Eastern European states which were subsequently (re-) included into the European framework were, to a large extent, crafted and constituted through transnational processes involving a fundamental re-structuring of political economy institutions in relation to labour markets and social provisions. This process is, as testified by the Troika, still ongoing. A substantial part of the history of Europe from 1945 onwards is therefore the history of the transnational imposing of a social-market economy framework on (West-)Germany and its subsequent spread via European institutions to ever larger parts of Europe.

The transnational imposition of a specific type of national political economy institutions is furthermore to be seen as part of broader state-building processes oriented towards establishing a specific realm of legally constituted public power which is separated from and substantially distinct from private power. The understanding of the evolutionary trajectory of political economy institutions in Europe therefore need to be seen in a different light than the methodological nationalist outlooks which has been dominant so far.

The causes for the differences between today's development and the previous developments should therefore not be found in the dual (trans-)national character of political economy institutions but rather in the change of the substantial economic paradigm guiding 
economic policy in both national and transnational settings. Firstly, the 'micro-economic constitution', as embodied in the four freedoms of the internal market and the EU competition regime, which gradually evolved from the 1950s onwards has since the 1990s been complemented with a macro-economic constitution, as embodied in the Economic and Monetary Union (EMU), which rests firmly on a different paradigm than the Keynesian paradigm which served as the backdrop for the immediate post-WWII re-constitution of European social market economies. Secondly, this post-Keynesian essentially monetarist paradigm might be seen as more compatible with liberal and Universalist approaches to welfare state development and their corresponding institutional formations than the corporatist approaches which have remained dominant in the most southern Member States. Thirdly, when combined with the different degrees of evolutionary maturity of the economic and social constitutions of the EU itself the actual choice of policy tools deployed by the Troika might be seen as reflecting a setup which is highly dis-favourable to the type of institutional arrangements which have been the central to these states

The core normative issue emerging when analysing the issue of constitutional imbalances between social and economic dimensions in the European context therefore seems to be the question of the deeper purpose of transnational arrangements. Should transnational frameworks be deployed as instruments of harmonisation of European social models or rather as vehicles aimed at safeguarding the diversity of national political economy regimes respecting their historical evolution? As it is now, the latter approach is, on the basis of an institutional trajectory dating back to the immediate post-WWII period, the dominant one. 


\section{References}

Barbezat, D. (1991) ‘A Price For Every Product. Every Place: The International Steel Export Cartel, 1933-39’. Business History, Vol. 33, No. 4, pp. 68-86.

Bast, J. (1999) Totalitärer Pluralismus. Zu Franz L. Neumanns Analysen der politischen und rechtlichen Struktur der NS-Herrschaft (Tübingen: Mohr Siebeck).

Bertilorenzi, Marco. (2014) 'Business, finance, and politics: the rise and fall of international aluminium cartels, 1914-45’, Business History, Vol. 56, No. 2, pp. 236 - 269.

DeLong, Bradford. J and Eichengreen, B (1993) The Marshall Plan as a Structural

Adjustment Programme, in Dornbusch, R., Nölling, W. and Layard, R. (eds), Postwar

Economic Reconstruction: Lessons for Eastern Europe (London: Anglo-German Foundation for the Study of Industrial Society).

Brunkhorst, H. (2014) Critical Theory of Legal Revolutions: Evolutionary Perspectives (London: Bloomsbury, 2014).

Bugaric, B. (2014) 'Law and Development in Central and Eastern Europe: Neoliberal Developmental State and its Problems’. In Peerenboom, R. and Ginsburg, T. (eds.) Law and Development of Middle-Income Countries: Avoiding the Middle-Income Trap (Cambridge: Cambridge University Press), 131-55.

Carsalade, Y. (2002) Les grandes étapes de l'histoire économique: revisiter le passé pour comprendre le présent et anticiper l'avenir (Paris: Ecole Polytechnique).

Chernilo, D. (2007) A Social Theory of the Nation-state: The Political Forms of Modernity beyond Methodological Nationalism (Abingdon: Routledge).

Crouch, C. (1994) Industrial Relations and European State Traditions (Oxford/New York: Oxford University Press).

Diamandouros, P. N. (2013) 'Postscript: Cultural Dualism Revisited’. In Gropas, R. and 
Kouki H. (eds.): The Greek Crisis and European Modernity (Basingstoke, Palgrave Macmillan), $208-32$.

Esping-Andersen, G. (1990) The Three Worlds of Welfare Capitalism (Cambridge: Polity Press).

Esposito, C. (1994) America's Feeble Weapon: Funding the Marshall Plan in France and Italy, 1948-1950 (Westport CT: Greenwood Press).

Feldman, G.D. (1977) Iron and Steel in the German Inflation 1916-23 (Princeton NJ: Princeton University Press).

Fossum, J.E. and Menéndez, A.J. (2011) The Constitution’s Gift: A Constitutional Theory for a Democratic European Union (Lanham MD: Rowman \& Littlefield).

Gillingham, J. (1991) Coal and Steel and the Rebirth of Europe 1945-55. The Germans and French from Ruhr Conflict to Economic Community (Cambridge: Cambridge University Press).

Hall, P.A., and Soskice, D. (2001) (eds.) Varieties of Capitalism: The Institutional Foundations of Comparative Advantage (Oxford: Oxford University Press).

Harste, G. (2015) 'The Democratic Surplus that Constitutionalised the European Union: Establishing Democratic Governance through Intermediate Institutions’. In Hartmann, E. and Kjaer, P. F. (eds) The Evolution of Intermediary Institutions in Europe (Basingstoke, Palgrave Macmillan), 199-215.

Herrigel, G. (2000) ‘American Occupation, Market Order, and Democracy: Reconfiguring the Steel Industry in Japan and Germany after the Second World War'. In Zeitlin, J. and Herrigel, G. (eds.) Americanization and its Limits: Reworking US Technology and Management in Post-War Europe and Japan (Oxford: Oxford University Press), 340-99.

Hilger, S. (1998) 'Welfare Policy in German Big Business after the First World War: 
Vereinigte Stahlverke AG, 1926-33’. Business History, Vol. 40, No. 1, pp.50-76.

Hinde, J. (1998) 'Sonderweg’. In Buse, D. and Doerr, J. (eds.) Modern Germany. An

Encyclopedia of History, People and Culture 1871-1990, Volume 2 (New York: Garland Publishing), 934 - 35.

Hurrelmann, A., Leibfried, S., Martens, K., and Mayer, P. (2007) (eds.) Transforming the Golden-Age Nation State (Basingstoke: Palgrave Macmillan).

Joerges, C. (2016) 'What is Left of the European Economic Constitution II?: From Pyrrhic Victory to Cannae Defeat'. In Kjaer, P. F. and Olsen, N. (eds.) Critical Theories of Crisis in Europe: From Weimar to the Euro (Lanham MD: Rowman \& Littlefield), 143 - 60.

Kaiser, W. and Schot, J. (2014), Writing the Rules for Europe: Experts, Cartels, International Organizations (Basingstoke: Palgrave Macmillan).

Kjaer, P.K. (2014) 'Towards a Sociology of Intermediary Institutions: The Role of Law in Corporatism, Neo-Corporatism and Governance’. In Rask Madsen, M. and Thornhill, C. (eds.) Law and the Formation of Modern Europe: Perspectives from the Historical Sociology of Law (Cambridge: Cambridge University Press), 117 - 141.

Kjaer, P.K. (2015) 'Context Construction through Competition: The Prerogative of Public Power, Intermediary Institutions and the Expansion of Statehood through Competition', Distinktion, Vol. 16, No. 2, pp. 146-66.

Kjaer, P.K. (2017) 'European Crises of Legally-Constituted Public Power: From the 'Law of Corporatism' to the 'Law of Governance’', European Law Journal, Vol. 23, No. 5, $417-430$.

Kjaer, P.F., and Olsen, N. (2016) (eds.) Critical Theories of Crisis in Europe: From Weimar to the Euro, (Lanham MD: Rowman \& Littlefield).

Kronstein, H. (1952) ‘Bargaining in Germany: Before 1933 and after 1945’, The American Journal of Comparative Law, Vol. 1, No. 3, 199-214. 
Maier, C.S (1975) Recasting Bourgeois Europe. Stabilization in France, Germany and Italy in the Decade after World War I (Princeton, NJ: Princeton University Press).

Manoïlescu, M. (1929) Théorie du protectionnisme et de l'échange international (Paris: Marcel Giard).

Milward, A.S. (2000) The European Rescue of the Nation-State, 2nd edition (Abingdon/New York: Routledge).

Neumann, F.L. (1930a [1996]) ‘Labor Law in Modern Society’. In Scheuerman, W.E. (ed.), The Rule of Law Under Siege: Selected Essays of Franz L. Neumann and Otto Kirchheimer (Berkeley CA: University of California Press), 231-42.

Neumann, F.L. (1930b) 'Die soziale Bedeutung der Grundrechte in der Weimarer Verfassung‘, Die Arbeit: Zeitschrift für Gewerkschaftspolitik und Wirtschaftskunde, Nr. 9, pp. 569-636.

Neumann, F.L. (1930c [1996]) ‘The Decay of German Democracy’. In Scheuerman, W.E. (ed.), The Rule of Law Under Siege: Selected Essays of Franz L. Neumann and Otto Kirchheimer (Berkeley CA: University of California Press) 29-43.

Neumann, F.L. (1933 [1996]) 'The Change in the Function of Law in Modern Society’. In Scheuerman, W.E. (ed.), The Rule of Law Under Siege: Selected Essays of Franz L. Neumann and Otto Kirchheimer (Berkeley, CA: University of California Press), 10141.

Neumann, F.L. (1944 [2009]) Behemoth: The Structure and Practice of National Socialism 1933-44 (Chicago IL: Ivan R. Dee)

Patel, K.P. and Schweitzer, H. (2013) (eds.) The Historical Foundations of EU Competition Law (Oxford: Oxford University Press).

Scharpf, F. (1988) 'The Joint Decision Trap: Lessons from German Federalism and European Integration’. Public Administration, Vol. 66, 3, No. pp. 239-278. 
Scharpf, F. (2010) 'The Asymmetry of European Integration. Or Why the EU Cannot Be a ‘Social Market Economy’. Socio-Economic Review, Vol. 8, Nr. 2, pp. 211-50.

Schmitter, P.C. (1974) 'Still the Century of Corporatism?'. The Review of Politics, Vol. 36, No. 1, pp. 85-131.

Schmitter, P.C., and Lehmbruch, G. (1979) Trends Toward Corporatist Intermediation (Thousand Oaks CA: SAGE).

Schröter, Harm G. (2013) 'Cartels Revisited. An Overview on Fresh Questions, New Methods, and Surprising Results’, Revue économique, Vol. 64, Nr. 6, pp. 989-1010. Sinzheimer, H., Kahn-Frund, O., and Ramm, T. (1976) (eds.) Arbeitsrecht und Rechtssoziologie: Gesammelte Aufsätze und Reden. Band 1 (Frankfurt am Main: EVA).

Streeck, W. (1997), ‘German Capitalism: Does it Exist? Can it Survive?’. In Crouch C. and Streeck, W. (eds.), Political Economy of Modern Capitalism: Mapping Convergence and Diversity (London/Thousand Oaks: Sage), 33-54.

Streeck, W. (2008) Re-Forming Capitalism. Institutional Change in the German Political Economy (Oxford: Oxford University Press).

Thornhill, C. (2016) 'The Constitutionalisation of Labour Law and the Crisis of National Democracy'. In Kjaer, P. F. and Olsen, N (eds.), Critical Theories of Crisis in Europe: From Weimar to the Euro (Lanham MD: Rowman \& Littlefield), 89-105.

Torp, C. (2016) ‘The Adenauer Government’s Pensions Reform of 1957 - A Question of Justice'. German History, Vol. 34, No. 2, pp. 237-57.

Tuori, K. (2010) ‘The Many Constitutions of Europe’. In Tuori, K. and Sankari, S. (eds.), The Many Constitutions of Europe (Farnham: Ashgate), 3 - 30.

Tüselmann, H., and Heise, A. (2000) 'The German Model of Industrial Relations at the 
Crossroads: Past, Present and Future', Industrial Relations Journal, Vol. 31, No. 3, pp. 162-76.

Warner, I. (1989) 'Allied-German Negotiation on the Deconcentration of the West German Steel Industry’. In Turner, I. (ed.), Reconstruction in Post-War Germany: British Occupation Policy and the Western Zones (Oxford: Berg), 155-85.

Warner, I. (1996) 'Steel and Sovereignty: The Deconcentration of the West German Steel Industry 1949-1954’ (Mainz: Verlag Philipp von Zabern). 